\title{
EXCRETION LEVEL OF TRACE MINERALS IN BROILERS FED ORGANIC MINERAL
}

\section{NÍVEIS DE EXCREÇÃO DE MICROMINERAIS EM FRANGOS DE CORTE ALIMENTADOS COM MINERAIS ORGÂNICOS}

\author{
Leticia Carvalho ${ }^{1}$ \\ Veridiana Limão ${ }^{1 *}$ \\ Naiara Simarro Fagundes ${ }^{2}$ \\ Evandro Fernandes ${ }^{1}$ \\ ${ }^{1}$ Universidade Federal de Uberlândia, Uberlândia, MG, Brazil \\ ${ }^{2}$ Escola Superior de Agricultura Luiz de Queiróz, USP, Piracicaba, SP, Brazil. \\ *Corresponding author - verilimao@gmail.com
}

\begin{abstract}
The aim of this current study was to determine the excretion level of the trace organic minerals copper, iron, manganese, and zinc added to broiler diets at different inclusion levels. The treatments consisted of a corn and soybean meal based diet supplemented with inorganic minerals or levels of organic minerals: basal diet containing $0 \%$ of microminerals of organic source $(\mathrm{MO}), 50 \% \mathrm{MO}, 75 \% \mathrm{MO}$, and $100 \%$ MO. Excretion levels of organic trace minerals varied quadratically in relation to the inclusion levels of organic minerals. The inclusion levels of $50 \%$ and $75 \%$ of organic minerals led to animals with lower excretion levels of all trace elements evaluated. The performance variables did not suffer any influence of treatments, even when the amount of organic minerals was equivalent to $50 \%$ of the recommended levels. The diet with the addition of trace organic minerals at the level of $50 \%$ is more efficient since it provides lower levels of trace minerals excretion keeping poultry performance.
\end{abstract}

Keywords: mineral nutrition; organic sources; poultry production; productive performance.

\section{Resumo}

Objetivou-se com o presente trabalho determinar o nível de excreção dos microminerais orgânicos cobre, ferro, manganês e zinco adicionados as dietas de frangos de corte em diferentes níveis de inclusão. Os tratamentos consistiram de uma dieta a base de milho e farelo de soja suplementada com minerais na forma inorgânica ou porcentagens de minerais orgânicos: os tratamentos consistiram em dieta basal contendo $0 \%$ de microminerais de fonte orgânica (MO), 50\% MO, 75\% MO e 100\% MO. Os níveis de excreção de microminerais orgânicos variaram de forma quadrática em relação aos níveis de inclusão dos minerais orgânicos. Nos níveis de inclusão de $50 \%$ e $75 \%$ de minerais orgânicos os animais apresentaram os menores níveis de excreção de todos os microminerais avaliados. As variáveis de desempenho não sofreram qualquer influência dos tratamentos, mesmo quando a quantidade de minerais orgânicos foi o equivalente a $50 \%$ dos níveis recomendados. A dieta com a inclusão dos microminerais no nível de $50 \%$ na forma orgânica se mostrou mais eficiente já que 
proporcionou os menores níveis de excreção dos microminerais, mantendo o desempenho das aves. Palavras-chave: avicultura; desempenho produtivo; fontes orgânicas; nutrição mineral.

Received on: December 2nd, 2014.

Accepted on: May 22nd, 2018.

\section{Introduction}

The current trace mineral levels used as a reference in poultry feed formulation are based on values from old surveys ${ }^{(1)}$ and they did not follow the genetic progress continuously experienced by commercial broiler strains.

Trace minerals are important in poultry feeding once they are involved in several biochemical processes, which are essential to growth and development, especially bone development ${ }^{(2)}$. They act as catalysts of the majority of enzymes and hormone systems predominantly. Mineral deficiencies can affect the animal metabolic and productive performance ${ }^{(3)}$, despite being needed in small amounts for continued growth and life ${ }^{(4)}$.

Mineral supplementation in animal diets is commonly done in the inorganic form because they are likely to interact among themselves and with other compounds in the digestive tract. As they are added at levels above the broiler's requirements, the result is an excess of nutrients in the diets.

The high concentration of minerals in animal waste can lead to soil contamination and reach the deepest levels up to the groundwater tables ${ }^{(5)}$. The mineral pollution potential allied to the goal of achieving the best broiler production efficiency have stimulated new discussion and research aiming at more bioavailable nutrients that enable a better utilization by the animal organism and, at the same time, minimize the environmental impacts generated by the activity.

In this context, interests in more bioavailable mineral sources are growing, such as complex organic trace minerals, called organic trace minerals. Once they are associated with organic molecules, the organic minerals are more stable to $\mathrm{pH}$ variations along the digestive tract of the bird ${ }^{(6)}$, showing thus more digestibility and, which leads to less excretion of these minerals.

Organic minerals can be a more efficient way to improve the minerals availability, providing a better nutrient absorption from feed, leading to better animal performance, maximizing profits, and minimizing costs ${ }^{(7)}$.

Thus, the current study aimed to determine the excretion level of trace mineral (copper, iron, manganese, and zinc), associated in its organic form, added to broiler diets at different inclusion levels and its effect on broiler performance.

\section{Material and Methods}

The experiment was carried out at the Poultry Experiment Farm, at Glória Farm, Faculty of Veterinary Medicine of the Federal University of Uberlândia in Uberlândia, Minas Gerais state. Throughout the experimental period, the animals remained in a barn made of masonry and metal structure, covered with cement tile, concrete floor and screened walls. The environment inside the barn was controlled through ceiling tiles made of plastic especially for poultry industry, mechanically-driven side curtains, ceiling sprinklers, fans, and an environment monitoring electronic central, besides artificial lighting. During the experimental period, the birds received water and food ad libitum with a diet 
based on corn and soybean meal (Table 1).

For this study, 48 30-day old female broiler were used. The animals were placed in cages, two birds per cage, and distributed in a completely randomized design, consisting of four treatments and six repetitions and two birds per repetition. The birds were submitted to a two-day adjustment period for diets and management used during the experimental period.

The treatments consisted of a corn and soybean meal-based diet supplemented with minerals in inorganic form or organic mineral percentages. Treatment 1 was the basal diet with $100 \%$ of inorganic minerals (control) in the form of salts in the mineral premix. The other treatments consisted of the basal diet added to a chelated minerals mixture (copper, iron, manganese, and zinc), partially hydrolyzed proteins, and amino acids in the organic form (OM), in percentages of $100 \%(100 \%$ of minerals in organic forms), $75 \%$ (75\% of minerals in organic form and $0 \%$ of minerals in inorganic form), and $50 \%$ (50\% of the minerals in organic form and $0 \%$ of minerals in inorganic form).

Trays were installed in the cages to cover their bottom and allow excreta collection. After a 24-hour fasting period, the experimental diets were fed ad libitum for four days and at the end of the fourth day, birds they were submitted to a new 24-hour fasting period. The fast regime was adopted to ensure that the excreta samples collected were only those from the experimental period. The total excreta collection was performed twice a day for five days since the beginning of feeding the experimental diets. The excreta collected were placed in pre-labeled plastic bags, according to each treatment and repetition, and stored under refrigeration.

Feed and birds were weighed in the beginning and at the end of the excreta collection period after fasting to determine the mean weight gain and feed intake, respectively. Feed conversion was calculated based on the ratio between feed intake and weight gain during the evaluated period.

At the end of the experiment, excreta and feed samples were sent to the Animal Nutrition Laboratory at the Faculty of Veterinary Medicine of the Federal University of Uberlândia for analyses performance. The analysis results of mineral composition of the experimental diets are shown in Table 2.

After thawing at room temperature, excreta were weighted, homogenized and samples were taken from each treatment. These were then dried in a forced ventilation oven at $55^{\circ} \mathrm{C}$ for 72 hours and crushed in a conventional mill.

One gram of each feed and excreta sample was weighted, packed in porcelain crucibles and placed in a muffle at $600{ }^{\circ} \mathrm{C}$ for two hours. The ashes were cooled in a desiccator, weighted, and diluted in 20 $\mathrm{mL}$ of hydrochloric acid solution 1:1. After the homogenization, filtering on filter paper was performed, the solution was transferred to a 100-mLflask, and the volume was completed with distilled water. Then, the solutions were taken to the atomic absorption spectrophotometer for reading the minerals, copper, iron, zinc and manganese from the experimental diets and excreta.

After checking the residuals normality and their variances in homogeneity, data were submitted to analyses variance and regression $(\mathrm{p}<0.05)$.

This study was analyzed by the ethics committee in animals, N. 253/13 for protocol registration at CEUA/UFU 118/13 and approved in 01/27/2014. 
Table 1. Percentage and calculated composition of experimental diets and inclusion levels of the organic minerals (OM) copper, iron, manganese, and zinc

\begin{tabular}{|c|c|c|c|c|}
\hline Ingredients & $\begin{array}{l}\text { Pre-starter } \\
\text { (1-7dias) }\end{array}$ & $\begin{array}{l}\text { Starter } \\
\text { (8-21dias) }\end{array}$ & $\begin{array}{l}\text { Growth } \\
\text { (22-33dias) }\end{array}$ & $\begin{array}{l}\text { Pre- } \\
\text { slaughter }\end{array}$ \\
\hline Corn & 55.68 & 54.18 & 58.20 & 64.41 \\
\hline Soybeanmeal & 36.87 & 36.36 & 32.53 & 26.92 \\
\hline Oil & 3.09 & 5.46 & 5.54 & 5.15 \\
\hline DicalciumPhosphate & 2.08 & 1.83 & 1.85 & 1.72 \\
\hline Limestone & 0.91 & 0.95 & 0.84 & 0.83 \\
\hline Common salt & 0.39 & 0.40 & 0.35 & 0.36 \\
\hline L-lysine & 0.28 & 0.13 & 0.06 & 0.12 \\
\hline DL-Methionine & 0.29 & 0.29 & 0.23 & 0.20 \\
\hline Premix (vit. + mineral) & $0.40^{1}$ & $0.40^{1}$ & $0.40^{2}$ & $0.30^{3}$ \\
\hline Total & 100 & 100 & 100 & 100 \\
\hline \multicolumn{5}{|l|}{ CalculatedComposition } \\
\hline $\mathrm{ME}(\mathrm{kcal} / \mathrm{kg})$ & 2960 & 3050 & 3150 & 3200 \\
\hline CrudeProtein (\%) & 22.90 & 22.83 & 19.73 & 18.31 \\
\hline Lysine (\%) & 1.46 & 1.30 & 1.19 & 1.14 \\
\hline Methionine (\%) & 0.69 & 0.58 & 0.55 & 0.53 \\
\hline Met+Cist.(\%) & 1.05 & 0.93 & 0.87 & 0.75 \\
\hline Calcium (\%) & 0.95 & 0.90 & 0.84 & 0.80 \\
\hline AvailablePhosp.(\%) & 1.89 & 0.45 & 0.42 & 0.39 \\
\hline Sodium (\%) & 0.22 & 0.22 & 0.21 & 0.2 \\
\hline \multicolumn{5}{|l|}{ InclusionLevels } \\
\hline Minerals (mg/kg) & $0 \% \mathrm{OM}$ & $50 \% \mathrm{OM}$ & $75 \% \mathrm{OM}$ & $100 \% \mathrm{OM}$ \\
\hline Cooper & 6.00 & 3.00 & 4.50 & 6.00 \\
\hline Iron & 30.00 & 15.00 & 22.50 & 30.00 \\
\hline Manganese & 70.00 & 35.00 & 52.50 & 70.00 \\
\hline Zinc & 50.00 & 25.00 & 37.50 & 50.00 \\
\hline
\end{tabular}

${ }_{1}$ MC- Starter Chicken Mix - Composition per productkilogram - Vit.A 2,750,000 UI; Vit.D3 500,000 IU; Vit.E 4,000 $\mathrm{mg}$; Vit. $K_{3} 375 \mathrm{mg}$; Vit. $B_{1} 300 \mathrm{mg}$; Vit. $B_{2} 1,125 \mathrm{mg}$; Vit. $B_{6} 500 \mathrm{mg}$; Vit. $B_{12} 4,000 \mathrm{mcg}$; niacin $8,750 \mathrm{mg}$; calcium pantothenate $2,500 \mathrm{mg}$; folic acid $100 \mathrm{mg}$; biotin $15 \mathrm{mg}$; selenium $62.5 \mathrm{mg}$; methionine $420 \mathrm{~g}$; choline $65,000 \mathrm{mg}$; iron $7,500 \mathrm{mg}$; cooper $2,250 \mathrm{mg}$; manganese $15,000 \mathrm{mg}$; zinc $15,000 \mathrm{mg}$; $250 \mathrm{mg}$; promoter $96 \mathrm{~g}$; coccidiostat $93,75 \mathrm{~g}$; antioxidant $30 \mathrm{~g}$.

${ }^{2} \mathrm{MC}$ - GrowthChicken Mix - Composition per productkilogram - Vit.A 10,000,000 IU; Vit. $D_{3}$ 2,500,000 UI; Vit.E $17,500 \mathrm{IU}$; Vit. $K_{3} 2,000 \mathrm{mg}$; folic acid $500 \mathrm{mg}$; pantothenic acid $15 \mathrm{mcg}$; Vit. $B_{1} 1500 \mathrm{mg}$; Vit $B_{12} 15000 \mathrm{mcg}$; biotin $60 \mathrm{mg}$; niacin $25 \mathrm{mg}$; Vit. $B_{6} 2000 \mathrm{mg}$; Vit. $B_{2} 7500 \mathrm{mg}$; iron $30 \mathrm{~g}$; cooper $6 \mathrm{~g}$; zinc $50 \mathrm{~g}$; manganese $70 \mathrm{~g}$; I $1 \mathrm{~g}$; selenium $0.35 \mathrm{~g}$; choline $0.20 \mathrm{~g}$.

${ }^{3}$ MC- Pre-slaughterChicken Mix - Composition per product kilogram - Vit.A 900,000 IU; Vit. D3 150,000 IU; Vit. E $1,500 \mathrm{mg}$; Vit. $K_{3} 150 \mathrm{mg}$; Vit. $B_{1} 90 \mathrm{mg}$; Vit. $B_{2} 300 \mathrm{mg}$; Vit. $B_{6} 120 \mathrm{mg}$; Vit. $B_{12} 900 \mathrm{mcg}$; niacin $1,500 \mathrm{mg}$; calciumpantothenate $1,200 \mathrm{mg}$; biotin $4.5 \mathrm{mg}$; selenium $60 \mathrm{mg}$; methionine $301 \mathrm{~g}$; choline $43,680 \mathrm{mg}$; iron $7,500 \mathrm{mg}$; cooper $2,250 \mathrm{mg}$; manganese $15,000 \mathrm{mg}$; zinc $15,000 \mathrm{mg}$; $250 \mathrm{mg}$; antioxidant $30 \mathrm{~g}$. 
Table 2. Mineral composition of the experimental diets at different levels of organic minerals (MO) inclusion

\begin{tabular}{|c|c|c|c|c|}
\hline \multicolumn{5}{|c|}{ Mineral Composition } \\
\hline Inclusionlevels & $\begin{array}{l}\text { Cooper } \\
(\mathrm{mg} / \mathrm{kg})\end{array}$ & Iron (mg/kg) & $\begin{array}{l}\text { Manganese } \\
(\mathrm{mg} / \mathrm{kg})\end{array}$ & Zinc (mg/kg) \\
\hline $0 \% \mathrm{OM}$ & 11.61 & 1024.76 & 42.69 & 66.69 \\
\hline $50 \% \mathrm{OM}$ & 2.23 & 698.53 & 21.54 & 45.18 \\
\hline $75 \% \mathrm{OM}$ & 7.15 & 803.38 & 38.95 & 53.84 \\
\hline $100 \% \mathrm{OM}$ & 10.09 & 1003.56 & 41.52 & 61.31 \\
\hline
\end{tabular}

\section{Results}

The levels of excretion of organic trace minerals showed a quadratic behavior in relation to the levels of inclusion of organic minerals. Among the treatments studied, animals fed a non-organic minerals diet, that is, the ration with $100 \%$ of inorganic mineral, showed higher excretion levels of the trace elements copper, iron, manganese, and zinc (Figure 1). Similar behavior was observed for the animals fed $100 \%$ organic mineral diets. As for the inclusion levels of $50 \%$ and $75 \%$ of organic minerals, that is, for the diets composed of only $50 \%$ and $75 \%$ of the required amount of mineral in the organic form, the birds had the lowest excretion levels for all the evaluated trace minerals (Figure 1).

Excretion levels of $57 \%, 60 \%, 80 \%$ of copper, $85 \%, 88 \%, 99 \%$ of iron, $76 \%, 82 \%, 100 \%$ of manganese, and $75 \%, 77 \%, 88 \%$ of zinc were observed for treatments where the animals received a diet containing $50 \%, 75 \%$ and $100 \%$ of trace minerals in organic form, respectively, compared to the control ( $0 \%$ of organic mineral).
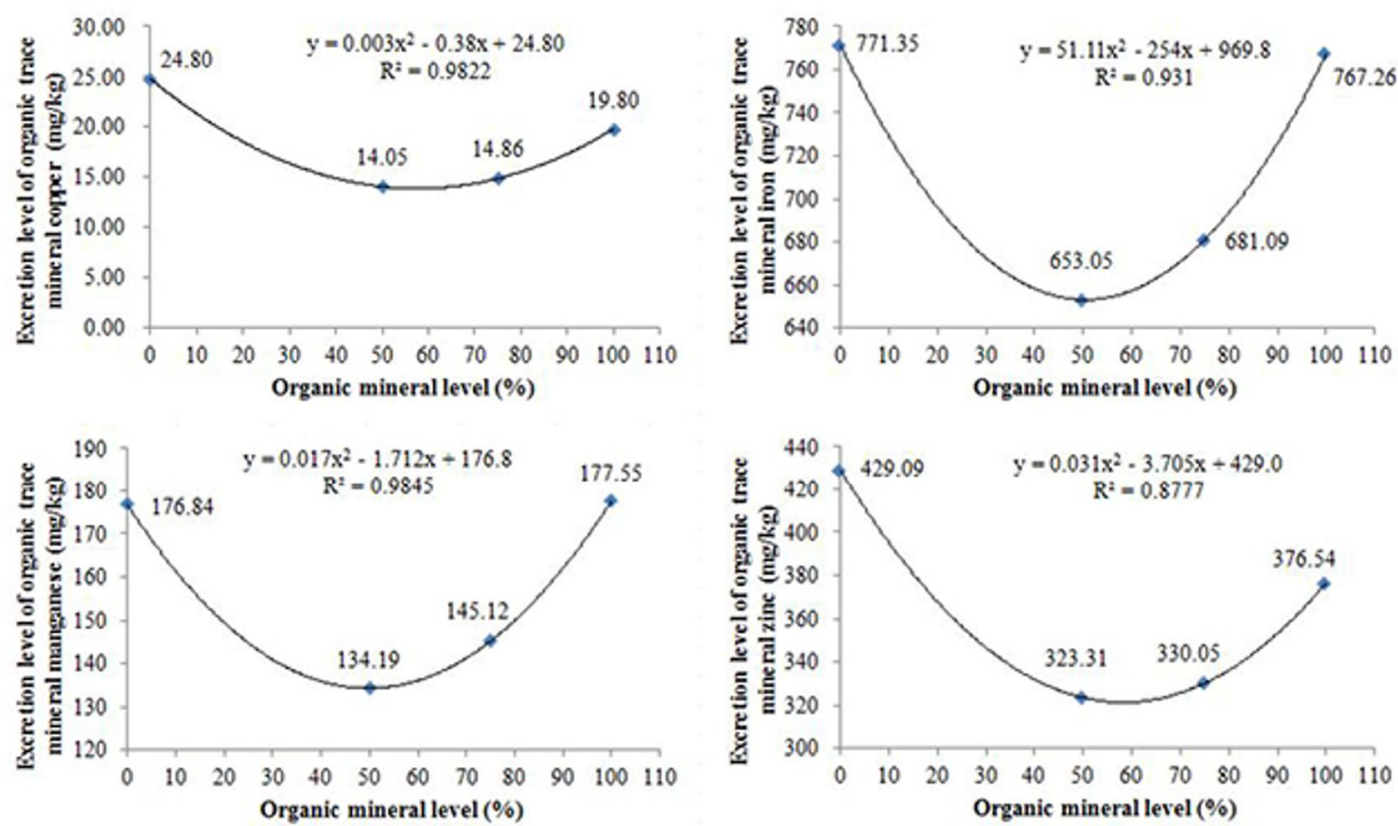

Figure 1. Excretion levels of organic trace minerals copper $(\mathrm{Cu})$, iron $(\mathrm{Fe})$, manganese $(\mathrm{Mn})$, and zinc $(\mathrm{Zn})$ in broiler diets from 30 to 37 days old at different inclusion levels. 
Table 3. Performance of broilers fed the organic trace minerals (OM) copper, iron, manganese, and zinc at different inclusion levels from 30 to 37 days of age

\begin{tabular}{lccc}
\hline Mineral level & $\begin{array}{c}\text { Mean } \\
\text { feedintake (g) }\end{array}$ & $\begin{array}{c}\text { Mean } \\
\text { weightgain }(\mathbf{g})\end{array}$ & $\begin{array}{c}\text { Feed } \\
\text { conversion }\end{array}$ \\
\hline $0 \% \mathrm{OM}$ & 825.00 & 266.67 & 3.11 \\
$50 \% \mathrm{OM}$ & 829.17 & 290.00 & 2.87 \\
$75 \% \mathrm{OM}$ & 845.83 & 302.00 & 2.80 \\
$100 \% \mathrm{OM}$ & 854.17 & 300.00 & 2.85 \\
\hline Pvalue & 0.8347 & 0.1018 & 0.1263 \\
Linear Regression & $\mathrm{NS}$ & $\mathrm{NS}$ & $\mathrm{NS}$ \\
QuadraticRegression & $\mathrm{NS}$ & $\mathrm{NS}$ & $\mathrm{NS}$ \\
\hline VC $(\%)$ & 7.81 & 10.37 & 9.12 \\
\hline
\end{tabular}

NS: not significant at $5 \%$ of probability $(\mathrm{P}<0.05)$.

\section{Discussion}

The lowest trace mineral excretion levels were described by Nollet et al. ${ }^{(5)}$, who evaluated 0-39 day-old broilers. The organic mineral concentration levels used in the diet were $7,4,4.5$, and 5 times lower for manganese, iron, zinc, and copper, respectively, compared to the level of these minerals in their inorganic form. Although these levels are much lower than the ones used in this study, the authors did not verify any performance loss.

The high levels of mineral excretion by the animals which received inorganic sourced supplementation is a consequence of the high concentration of these minerals in the composition of the control diet. In other words, these animals received higher mineral levels than their nutritional requirement. It is possible to infer that organic minerals interact less with other compounds and form less unavailable complexes in the intestinal lumen, contributing to a better absorption of these minerals in the intestine ${ }^{(5)}$. Thus, these minerals may be provided in smaller quantities, since they are organic, without causing any loss in growth and performance, besides producing excreta with lower mineral concentrations.

In order to minimize the impact of the animal production environmental, it is necessary to make the most of the feed potential, increasing retention of ingested nutrients, and reducing losses by excretion. It is important to integrate performance and economy improvement with environmental preservation.

The environmental agencies show increasingly growing concern in order to enable techniques that reduce environmental pollution within the production systems. Therefore, when minerals loss by excreta is reduced, environmental pollution also decreases. On average, organic mineral supplementation contributes to a reduction in mineral excretion ${ }^{(8)}$. In the current study, these reductions ranged from $1 \%$ to $43 \%$. Thus, the use of organic minerals may be an effective alternative to promote the reduction of environmental pollution as well as to bring positive results to the poultry industry.

Several studies have highlighted the efficiency of organic minerals to maintain broilers' performance when they are supplemented at lower levels than those usually practiced ${ }^{(1,5,9,10)}$. Leeson and Caston ${ }^{(11)}$ found a reduction in mineral excretion by using organic minerals at levels 14 times lower than those applied at inorganic mineral supplementation, without, however, affecting body weight, feed intake, and feed conversion.

The greatest availability of organic trace minerals is due to the shielding of minerals positive charge during chelation, which allows higher stability in $\mathrm{pH}$ variations in the digestive tract, resulting in less competition 
among the minerals with the same charge making the absorption of minerals by the intestine easier and reducing losses by excreta ${ }^{(6)}$.

In general, as mentioned before, minerals are added to diets in their inorganic form. Complexed minerals have been used to provide a higher bioavailability of these nutrients. However, the benefits seem to be hidden when the addition of the mineral occurs at higher levels. Bao et al. ${ }^{(12)}$ reported that, when mineral inclusion levels are high even in their organic form, mineral excretion tends to be greater than or equal to the levels excreted by birds fed inorganic minerals. Therefore, by the economic, productive, and environmental point of view, a lower inclusion of minerals is good to maintain or even improve birds performance combined with lower mineral excretion.

Mineral nutrition for birds does not seem to follow the technological advances and breed improvements experienced by the poultry industry over the past decades. There is a consensus that trace mineral supplementation levels practiced currently are far beyond the requirements. According to Leeson and Caston $^{(11)}$, to determine the optimal trace mineral supplementation level, it is imperative to identify their bioavailability in the main ingredients for diet formulations.

Therefore, studies with supplementation of organic minerals in broilers feed are important to maximize the animal use of nutrients, making the system more productive and economic while enabling the reduction of environmental pollution.

\section{Conclusion}

The diet with inclusion of organic trace minerals at the level of $50 \%$ seemed to be more efficient, since it provided lower trace minerals excretion levels while keeping poultry performance.

\section{References}

1. Petrovič V, Nollet L, Kováč G. Effect of dietary supplementation of trace elements on the growth performance and their distribution in the breast and thigh muscles depending on the age of broiler chickens. Acta Vet Brno.2010; 79:203-209.

2. Richards JD, Zhao J, Harrell RJ, Atweell CA, Dibner JJ. Trace mineral nutrition in poultry and swine. AsianAust. J. Anim. Sci. 2010; 23-1527-34.

3. Vieira SL. Chelated minerals for poultry. Rev. Bras. Cienc. Avic. 2008; 10:73-9.

4. Aksu, DS, Aksu T, Önel SE . Does inclusion at low levels of organically complexed minerals versus inorganic forms create a weakness in performance or antioxidant defense system in broiler diets? Int. J. Poult. Sci. 2012; 11:666-72.

5. Nollet L, Van Der Klis JD, Lensing M, Spring P. The effect of replacing inorganic with organic trace minerals in broiler diets on productive performance and mineral excretion. J Appl Poult Res. 2007; 16:592-7.

6. Bao YM, Choct M. Trace mineral nutrition for broiler chickens and prospects of application of organically complexed trace minerals: a review. Anim. Prod. Sci. 2009; 49:269-82.

7. Figueiredo Júnior JP, Costa FGP, Givisiez, PEN, Lima MR, Silva JHV, Figueiredo-Lima DF, Saraiva, EP, Santana, MHM. Substituição de minerais inorgânicos por orgânicos na alimentação de poedeiras semi pesadas. Arq Bras Med Vet Zootec 2013; 65:513-518. 
8.Swiatkiewicz S, Arczewska-Wlosek A, Józefiak D. The efficacy of organic minerals in poultry nutrition: review and implications of recent studies. Word's Poult. Sci. J. 2014; 70:475-86.

9. Tavares T, Mourão JL, Kay Z, Spring P, Vieira J, Gomes A, Vieira-Pinto M. The effect of replacing inorganic trace minerals with organic Bioplex ${ }^{\circledR}$ and Sel-Plex ${ }^{\circledR}$ on the performance and meat quality of broilers. J. Appl. Anim. Nutr. 2013; 2:1-7.

10. Zhao J, Shirley RB, Vazquez-Anon M, Dibner JJ, Richards JD, Fisher P, Hampton T, Christensen KD, Allard JD, Giesen AF. Effects of chelated trace minerals on growth performance, breast meat yield, and footpad health in commercial meat broiler. Appl Poult Res. 2010; 19:365-72.

11. Lesson S, Caston L. Using minimal supplements of trace minerals as a method of reducing trace mineral content of poultry manure. Anim Feed Sci Technol, 2008; 142:339-47.

12. Bao YM, Choct M, Iji PA, Bruerton K. The digestibility of organic trace minerals along the small intestine in broiler chickens. Asian-Aust J Sci. 2010; 23: 90-97. 